\title{
Kezdeti tapasztalataink az mpMR fúziós ultrahangvezérelt prosztatabiopsziával
}

\author{
Hüttl András Béla dr. ${ }^{\text {* }}$ - Korda Dávid Ádám dr. ${ }^{2 *}$ \\ Lénárd M. Zsuzsanna dr. ${ }^{2}$ - Szendrői Attila dr. ${ }^{1}$ - Rudas Gábor $\mathrm{dr}^{3}$ \\ Kalina Ildikó dr. ${ }^{3}$ - Fejér Bence dr. ${ }^{3}$ - Szabó József dr. ${ }^{4}$ \\ Takács Szabolcs dr. ${ }^{5}$ - Nyirády Péter dr. ${ }^{1}$
}

\author{
${ }^{1}$ Semmelweis Egyetem, Általános Orvostudományi Kar, Urológiai Klinika, Budapest \\ ${ }^{2}$ Semmelweis Egyetem, Általános Orvotudományi Kar, Transzplantációs és Sebészeti Klinika, Budapest \\ ${ }^{3}$ Semmelweis Egyetem, Általános Orvostudományi Kar, Orvosi Képalkotó Klinika, Budapest \\ ${ }^{4}$ Székelyudvarhelyi Városi Kórház, Sebészeti Osztály, Székelyudvarhely, Románia \\ ${ }^{5}$ Károli Gáspár Református Egyetem, Budapest
}

Bevezetés: A prosztatarák diagnosztikájában az utóbbi években paradigmaváltás történt. Az MR-vizsgálat fejlődése lehetővé tette a prosztatatumor gyanús elváltozásainak célzott mintavételét. Az mpMR fúziós biopszia pontos és költséghatékony módszer.

Célkitüzés: Célkitűzésünk az volt, hogy összegezzük az mpMR fúziós biopsziák terén szerzett tapasztalatainkat. Módszer: A Semmelweis Egyetem Urológiai Klinikáján 2017 és 2019 között 40, mpMR fúziós biopsziát végeztünk a BioJet-program segítségével, transperinealis behatolásból. Az MR-vizsgálatok kiértékelése a PI-RADS v2 ajánlása szerint történt. Megvizsgáltuk, hogy a laesiók PI-RADS-besorolása, elhelyezkedése, mérete, az extraprosztatikus terjedés jeleinek megléte, a páciensek PSA-, illetve PSAD-értékei, valamint a prosztata volumene befolyásolja-e a mintavételek kimenetelét.

Eredmények: A célzott mintavételek során pácienseink 80\%-ánál igazolódott malignitás. PI-RADS 5. és 4. besorolású laesiók esetén a detektációs ráta $91 \%$, illetve $85 \%$, míg PI-RADS 3. laesióknál $20 \%$ volt. A perifériás zóna elváltozásainál szignifikánsan magasabb volt a pozitív eredmény valószínúsége, mint a tranzicionális zóna laesióinál $\left(\mathrm{khi}^{2}(1)=\right.$ $6,555, \mathrm{p}=0,010$, Fisher-féle egzakt $\mathrm{p}=0,017, \mathrm{~V}=0,355)$. Az extraprosztatikus terjedés jelei és a magasabb PSADértékek növelték a pozitív minták valószínúségét $\left(\mathrm{khi}^{2}(\mathrm{l})=7,704, \mathrm{p}=0,006\right.$, Fisher-féle egzakt $\mathrm{p}=0,004, \mathrm{~V}=0,355$; illetve $0,47 \pm 0,50 \mathrm{ng} / \mathrm{ml}^{2}$ vs. $\left.0,18 \pm 0,17 \mathrm{ng} / \mathrm{ml}^{2} ; \mathrm{Z}=3,447, \mathrm{p}<0,001\right)$, míg az elváltozások mérete nem befolyásolta a kimenetelt. A prosztatavolumen szignifikánsan magasabb volt azoknál, akiknél nem igazolódott malignitás $(50,9 \pm 18,8 \mathrm{ml}$ vs. $119,6 \pm 91,6 \mathrm{ml} ; \mathrm{Z}=-3,505, \mathrm{p}<0,001)$.

Következtetések: Az elvégzett fúziós biopsziák detektációs rátája magasabb volt az irodalmi átlagnál. Eredményeink alapján a mintavételek kimenetelét befolyásolhatja az elváltozások PI-RADS-besorolása, elhelyezkedése, az extraprosztatikus terjedés, a PSAD-értékek, valamint a prosztatatérfogat. A fenti szempontok figyelembevételével kiválaszthatók azok a páciensek, akik a legtöbbet profitálhatnak a beavatkozásból.

Orv Hetil. 2020; 161(52): 2188-2194.

Kulcsszavak: prosztatarák, prosztatarák-diagnosztika, prosztata-MR, fúziós biopszia

\section{Our initial experiences with mpMRI-ultrasound fusion-guided prostate biopsy}

Introduction: The past decade has seen some major changes in the diagnostics of prostate cancer. Progress in MR imaging has allowed us to better visualise prostate cancer and thus perform targeted biopsies of tumour suspect lesions. mpMRI-ultrasound fusion-guided prostate biopsy is a precise and cost-effective method to diagnose prostate cancer.

Objective: The purpose of this study was to summarise our results in mpMRI-ultrasound fusion biopsy between 2017 and 2019 and compare them with the findings in the current literature.

*Megosztott első szerzők. 
Method: Between 2017 and 2019, fully 40, mpMRI-ultrasound fusion biopsies were performed transperineally using the BioJet fusion system at Semmelweis University Urology Clinic. The MRI evaluations were done in line with the PI-RADS v2 guidelines. It was analysed whether the PI-RADS score, the location of the tumour, lesion size, the signs of extraprostatic extension, PSA/PSAD density and prostate volume have an influence on the outcome of mpMRIultrasound fusion biopsy.

Results: Prostate cancer was diagnosed in $80 \%$ of the cases during targeted biopsies. The detection rate was $91 \%, 85 \%$, and 20\% for PI-RADS 5, 4 and 3 lesions, respectively. The detection rate was significantly higher for lesions located at the peripheral zone compared to the ones in the transitional zone $\left(\mathrm{khi}^{2}(1)=6.555, \mathrm{p}=0.010\right.$, Fisher-exact $\mathrm{p}=$ $0.017, \mathrm{~V}=0.355)$. Signs of extraprostatic extension and higher PSAD correlated with better detection $\operatorname{rate}\left(\mathrm{khi}^{2}(\mathrm{l})\right.$ $=7.704, \mathrm{p}=0.006$, Fisher-exact $\mathrm{p}=0.004, \mathrm{~V}=0.355 ;$ and $0.47 \pm 0.50 \mathrm{ng} / \mathrm{ml}^{2}$ vs. $0.18 \pm 0.17 \mathrm{ng} / \mathrm{ml}^{2} ; \mathrm{Z}=3.447$, $\mathrm{p}<0.001$, respectively). The size of the lesions did not influence the outcome. The analysis showed a significant correlation between large prostate volumes and negative biopsies $(50.9 \pm 18.8 \mathrm{ml}$ vs. $119.6 \pm 91.6 \mathrm{ml} ; \mathrm{Z}=-3.505$, $\mathrm{p}<0.001)$.

Conclusions: The detection rate of prostate cancer with targeted biopsies was higher than the data found in the international literature. The PI-RADS score, the location of the tumour, MRI signs of extraprostatic extension, PSAD and prostate volume had an influence on the detection rate. Our findings may promote a better selection of the best candidates for targeted biopsies in the future.

Keywords: prostate cancer, prostate cancer diagnostics, prostate MRI, fusion biopsy

Hüttl AB, Korda DÁ, Lénárd MZs, Szendrői A, Rudas G, Kalina I, Fejér B, Szabó J, Takács Sz, Nyirády P. [Our initial experiences with mpMRI-ultrasound fusion-guided prostate biopsy]. Orv Hetil. 2020; 161(52): 2188-2194.

(Beérkezett: 2020. június 8.; elfogadva: 2020. július 13.)

\section{Rövidítések}

ASAP $=($ atypical small acinar proliferation $)$ kis acinusok atipikus proliferációja; $\mathrm{mpMR}=$ multiparametrikus $\mathrm{MR} ; \mathrm{MR}=$ (magnetic resonance) mágneses magrezonancia; $\mathrm{PCa}=$ (prostate cancer) prosztatarák; PIN = prosztata intraepithelialis neoplasia; PI-RADS v2 = (Prostate Imaging-Reporting and Data System, version 2) a prosztataképalkotás-jelentési és -adatrendszer 2. verziója; PSA = (prostate-specific antigen $)$ prosztataspecifikus antigén; PSAD = (prostate-specific antigen density) a prosztataspecifikus antigén sürüsége; $\mathrm{RDV}=$ rectalis digitalis vizsgálat; TRUSB = (transrectal ultrasound biopsy) transrectalis ultrahangvezérelt biopszia

A prosztatarák az egyik leggyakoribb, férfiakat érintő daganatos megbetegedés, Európában az ötödik leggyakoribb daganatos halálok [1]. Hazánkban évente hozzávetőlegesen 4000 új esetet diagnosztizálnak, a betegség minden évben körülbelül 1600 ember haláláért felelős [2]. Az életkor előrehaladtával a betegség kialakulásának kockázata jelentősen nő [3].

A prosztatarák diagnózisához elengedhetetlen a prosztatabiopszia elvégzése, amelynek segítségével szövettanilag igazolható a daganatos betegség. Ultrahangvizsgálattal a prosztatatumorok jelentős része nem különíthető el a normális prosztataszövettől, emiatt ultrahangvezérléssel célzott mintavétel a legtöbb esetben nem végezhető [4]. Ennek kiküszöbölésére fejlesztették ki a prosztata 10-12 régiójából transrectalisan végzett, ultrahangvezérelt szisztematikus biopsziát (TRUSB), amelyet elsőként az 1980-as években alkalmaztak. Az eljárás során többszöri random mintavétel történik azzal a céllal, hogy a prosztata minden régiója lefedésre kerüljön. Ellentétben a többi daganatos betegség mintavételével, a TRUSB nem tekinthetô célzott biopsziának: az álnegatív eredmény aránya igen magas, irodalmi adatok alapján elérheti a $40-45 \%$-ot is [5]. A betegség megléte nem zárható ki teljes biztonsággal negatív biopsziás eredmény esetén sem, ezért ilyenkor kiemelkedóen fontos a beteg szoros követése és szükség esetén az ismételt mintavétel, melynek során az esetek 15-23\%-ában igazolódik prosztatarák [6]. Mindezek a diagnosztikus eljárások számos, sok esetben megterhelő vizsgálatot jelentenek a páciens számára, és szövődmények kockázatával, valamint jelentős anyagi költséggel és humánerőforrás bevonásával járnak világszerte az egészségügyben [7].

A prosztatarák diagnosztikájában az utóbbi években paradigmaváltás ment végbe. A PSA, a rectalis vizsgálat és a TRUSB mellett napjainkban egyre fontosabb szerepet kap a mágneses magrezonanciás (MR-) vizsgálat és az ezen alapuló célzott mintavétel [8]. Az MR-vizsgálat lehetővé teszi a prosztatarák érzékeny kimutatását. A vizsgálat során ábrázolódó gyanús laesiók mintavétele háromféleképpen történhet. A kognitív célzás során a mintavételt végző személy gondolatban rávetíti az MRvizsgálaton látott gyanús eltéréseket a transrectalis ultrahangvizsgálat képeire. Ez az eljárás nem igényel speciális berendezést, viszont hátránya a megfelelő célzásról való vizuális visszajelzés hiánya, továbbá az, hogy a mintavételt végző személy gyakorlottsága nagyban befolyásolja a kimenetelt [9]. A direkt (in-bore) MR-vezérelt mintavétel a relatíve nagy időigénye és költségessége miatt nem terjedt el a klinikai gyakorlatban [6]. Kevésbé költséges, viszont hasonlóan pontos és jól reprodukálható eljárás az 
1. táblázat |A páciensek klinikai adatai

\begin{tabular}{ll}
\hline Életkor & $67,3 \pm 5,9$ év \\
Indikáció & $\begin{array}{l}\text { Aktív követés: } 7 \text { eset } \\
\text { Tumorgyanú: } 33 \text { eset }\end{array}$ \\
PSA & $20,8 \pm 25,9 \mathrm{ng} / \mathrm{ml}$ \\
Prosztatatérfogat & $66,4 \pm 53,3 \mathrm{ml}$ \\
PSAD & $0,44 \pm 0,51 \mathrm{ng} / \mathrm{ml}^{2}$ \\
\hline
\end{tabular}

PSA $=$ prosztataspecifikus antigén; PSAD $=$ a prosztataspecifikus antigén sürüsége

2. táblázat |A tumorgyanús laesiók jellemzői az MR-vizsgálatok alapján

\begin{tabular}{|c|c|}
\hline Kiindulás & $\begin{array}{l}\text { Perifériás zóna: } 35 \text { laesio } \\
\text { Tranzicionális zóna: } 17 \text { laesio }\end{array}$ \\
\hline PI-RADS-besorolás & $\begin{array}{l}\text { PI-RADS 5.: } 22 \text { laesio ( } 13 \mathrm{PZ} ; 9 \mathrm{TZ}) \\
\text { PI-RADS } 4 .: 20 \text { laesio (20 PZ; } 0 \mathrm{TZ}) \\
\text { PI-RADS } 3 .: 10 \text { laesio ( } 2 \mathrm{PZ} ; 8 \mathrm{TZ})\end{array}$ \\
\hline Térfogat & $1,3 \pm 1,5 \mathrm{~cm}^{3}$ \\
\hline $\begin{array}{l}\text { Az extraprosztatikus } \\
\text { terjedés jelei }\end{array}$ & $17 / 52$ laesio \\
\hline
\end{tabular}

$\mathrm{MR}=$ mágneses rezonancia; PI-RADS = prosztataképalkotás-jelentési és -adatrendszer; $\mathrm{PZ}=$ perifériás zóna; $\mathrm{TZ}=$ tranzicionális zóna

mpMR fúziós ultrahangvezérelt prosztatabiopszia, melynek során egy program segítségével a korábbi MR-vizsgálat képeit fuzionálják a transrectalis ultrahangvizsgálat valós idejü képeivel [10]. Mindhárom ismertetett módszer bizonyítottan hatékonyabb a hagyományos TRUSBnál a klinikailag szignifikáns prosztatarák kimutatásában [11].

Az MR-képalkotáson alapuló célzott mintavétel további előnye a TRUSB-val szemben, hogy a klinikailag nem szignifikáns tumorok detektációs rátája alacsonyabb [12]. A klinikailag nem szignifikáns, alacsony kockázatú tumorok a betegek életkilátásait nem befolyásolják, diagnózisuk azonban a páciensek túlkezeléséhez vezethet, pszichés megterheléssel jár, és súlyos anyagi terhet ró az egészségügyi elátórendszerre [7]. A célzott mintavételeknek a klinikai gyakorlatba való beépítésével az ilyen tumorok kisebb valószínűséggel kerülnek felfedezésre.

Munkacsoportunk célja az volt, hogy összegezzük eddigi tapasztalatainkat a Magyarországon elsőként végzett mpMR fúziós biopsziák terén. További célunk volt, hogy megvizsgáljuk, milyen faktorok befolyásolják a mintavételek sikerességi rátáját, és ennek alapján milyen szempontokat érdemes figyelembe vennünk a jövôben a páciensek kiválasztásakor.

\section{Módszer}

A Semmelweis Egyetem Urológiai Klinikáján 2017 októbere és 2019 májusa között 40, mpMR fúziós ultrahangvezérelt prosztatabiopsziát végeztünk. Prospektív vizsgálatunkba olyan pácienseket vontunk be, akiket egy urológusokból, radiológusokból és aneszteziológusokból álló multidiszciplináris team alkalmasnak ítélt a beavatkozásra. A beválogatásra került betegeket indikáció szerint két csoportra oszthatjuk: korábban negatív TRUSB-n átesett (33 eset), illetve prosztatarák miatt aktív követés alatt álló betegek (7 eset). A vizsgálatba bevont páciensek klinikai adatait az 1. táblázat tartalmazza.

\section{Prosztata-MR-képalkotás}

A fúzióhoz szükséges MR-vizsgálatok kiértékelése két, urogenitalis diagnosztikában jártas radiológus konszenzusa alapján történt a PI-RADS v2 (Prostate ImagingReporting and Data System version 2) ajánlása szerint. A fúziós mintavételekhez olyan, 1,5 tesla és 3 tesla térerősségú MR-készülékkel végzett vizsgálatok képanyagát használtuk fel, amelyek teljesítették a PI-RADS v2 ajánlásában megszabott kritériumokat. A vizsgálati protokoll tartalmazta a prosztatára centrált multiplanáris T2-méréseket, axiális T1-mérést, magas b-értékű diffúziós méréseket és dinamikus kontrasztanyagos méréseket. Az MR-képek alapján kiszámítottuk a prosztata térfogatát $[\mathrm{ml}]$ az alábbi képlet segítségével: (maximális anteroposterior átmérő $[\mathrm{cm}]) \times($ maximális transzverzális átmérô $[\mathrm{cm}]) \times($ maximális longitudinális átmérô $[\mathrm{cm}]) \times$ 0,52. Meghatároztuk a prosztatában fellelhető laesiók összesített PI-RADS-pontszámát, az elváltozások pontos lokalizációját és térfogatát [ml] (lásd előbbi képlet), valamint regisztráltuk azokat az eseteket, amelyekben az MR-képek alapján felmerült az extraprosztatikus terjedés gyanúja. A PSA-sűrűség (PSAD) $\left[\mathrm{ng} / \mathrm{ml}^{2}\right]$ értékeit a szérum-PSA-szint $[\mathrm{ng} / \mathrm{ml}]$ és a prosztatavolumen $[\mathrm{ml}]$ hányadosaként kalkuláltuk. Az MR-vizsgálatok alapján a 40 betegnél 52 tumorgyanús elváltozást találtunk, amelyek jellemzőit a 2. táblázatban foglaltuk össze.

\section{Transperinealis ultrahangvezérelt $M R$ fúziós prosztatabiopszia}

A mintavételeket megelőzően az axiális síkú T2-súlyozott MR-képeket feltöltöttük a BioJet- (D\&K Technologies GmbH, Barum, Németország) programba. A prosztatát tartalmazó szeleteken bejelöltük a prosztata kontúrját, valamint minden tumorgyanús laesiót (1. ábra). A beavatkozás előtt a betegek egyszeri dózisú antibiotikumprofilaxisban (iv. ceftriaxon $1 \times 2 \mathrm{mg}$ ) részesültek. A mintavételek spinalis anesztéziában történtek, részben a fájdalommentesség, részben a páciensek teljes mozdulatlansága érdekében. A betegek kőmetsző helyzetbe való fektetését követően a perineumot Betadine oldattal fertőtlenítettük. A transrectalis ultrahangfej bevezetése után a BioJet-rendszer segítségével fuzionáltuk az MR- és a 'real-time' (valós idejü) ultrahangképeket (Falcon 2101; BK Medical, Herlev, Dánia). A mintavételekhez CORAZOR biopsziás pisztolyt (UROMED, Oststeinbek, Németország) használtunk, 18 G-s túvel 


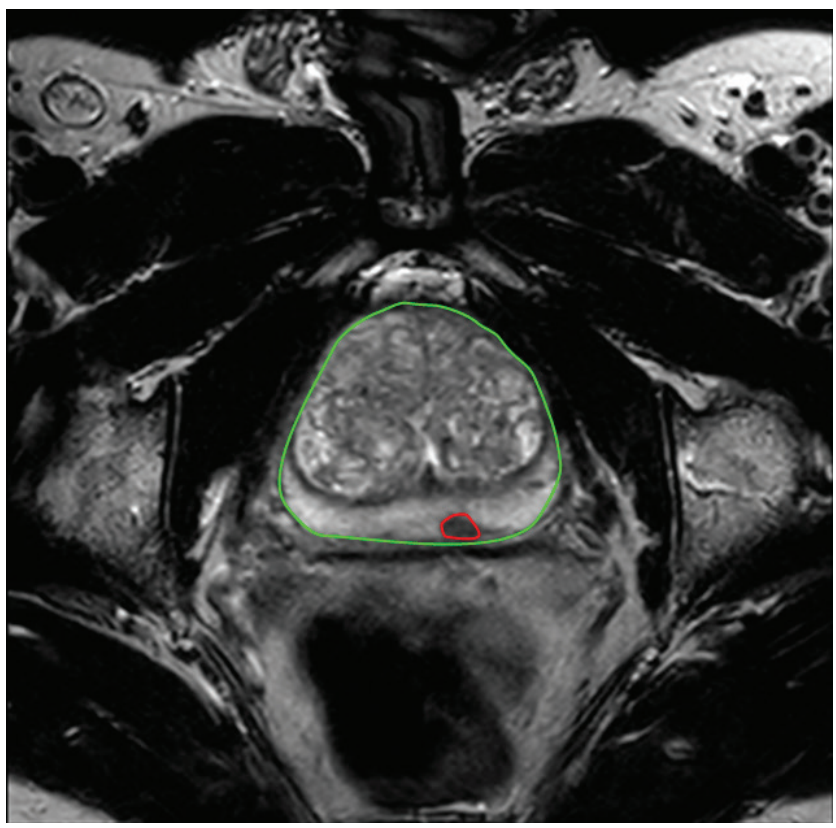

1. ábra

Axiális T2-súlyozott MR-képen a prosztata kontúrját zöld, a tumorgyanús területet piros vonal jelöli

$\mathrm{MR}=$ mágneses magrezonancia

$15 \mathrm{~mm}$ hosszúságú szövethengereket vettünk a gáton keresztül a prosztata állományából. A tumorgyanús területekből minimum 4 mintát vettünk, továbbá minden esetben random mintavételt is végeztünk (minimum 3-3 minta a prosztata két lebenyéből) (2. ábra). Szövődménymentes beavatkozás esetén a beteg másnap reggel távozott otthonába.

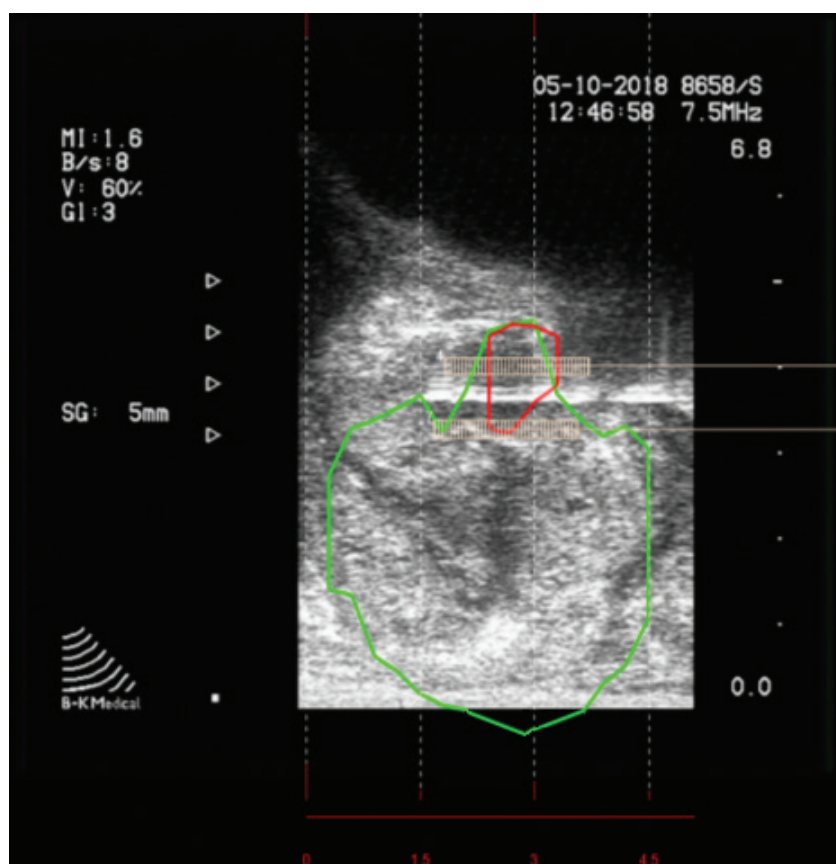

2. ábra

Egy beavatkozás közben készült felvételen megfigyelhető az elsütött biopsziás tű (hiperechogén vonal), amely áthatol a gyanús területen (piros vonal)

\section{Statisztika}

Adataink elemzéséhez az SPSS 25.0 statisztikai szoftvert (IBM Corporation, Armonk, NY, Amerikai Egyesült Államok) használtuk. Megvizsgáltuk, hogy az MR-vizsgálatokon ábrázolódott laesiók PI-RADS-besorolása, elhelyezkedése, mérete, az extraprosztatikus terjedés jeleinek megléte, a páciensek PSA-, illetve PSAD-értékei, valamint a prosztata volumene hogyan függ össze a szövettani eredménnyel. A kategoriális változók esetében kereszttáblás elemzést alkalmaztunk páronkénti összehasonlításban. A skála típusú változók esetében kétmintás t-próbával, Welch-féle d-próbával, illetve a Kolmogorov-Szmirnov-teszt alapján a normálistól szignifikánsan eltérő változók esetén Mann-Whitney-próbával hasonlítottuk össze a pozitív és a negatív kimenetelü csoportokat. A kereszttáblás elemzéseknél khi-négyzet-statisztikát és Fisher-féle egzakt tesztet alkalmaztunk, valamint az összefüggés nagyságának mérésére részben Cramérféle $\mathrm{V}$ együtthatót számítottunk, részben a cellákban található korrigált standardizált residualisokat vettük figyelembe. Az eredményeket $\mathrm{p}<0,05$ esetén tekintettük szignifikánsnak.

\section{Eredmények}

A betegek a beavatkozásokat jól tolerálták, invazív beavatkozást igénylő szövődmény egyik esetben sem lépett fel. Egy beavatkozás a tanulási fázist követően átlagosan 10-15 percig tartott. A mintavételt követóen 4 betegnél (10\%) teljes vizeletrekedést észleltünk, amit l esetben masszív haematuria, l esetben magas láz kísért. A leírt komplikációk konzervatívan eredményesen kezelhetők voltak.

A szövettani vizsgálatok eredményeinek megoszlását a 3. ábra szemlélteti. A feldolgozás alapján 32/40 (80\%) páciensnél igazolódott malignitás. Azoknak a betegeknek a csoportjában, akiknél a korábbi TRUSB-k negatív eredményt adtak, 26/33 (79\%) esetben detektáltunk tu-

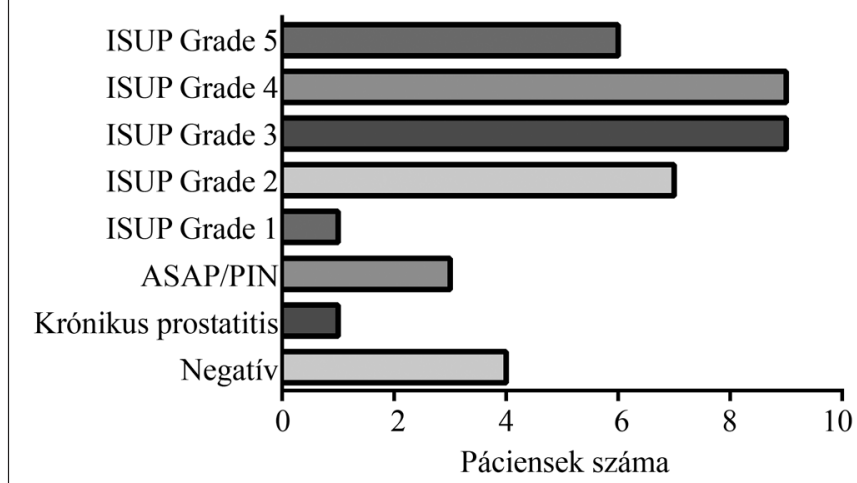

3. ábra A szövettani vizsgálat eredményeinek megoszlása
$\begin{aligned} & \text { ASAP = kis acinusok atipikus proliferációja; ISUP = Nemzetközi } \\ & \text { Urológiai Patológiai Társaság; PIN = prosztata intraepithelialis } \\ & \text { neoplasia }\end{aligned}$ 
mort a fúziós módszer segítségével. Az aktív követés alatt álló csoportban $5 / 7$ (71\%) esetben a korábban ismertnél magasabb gradusú tumor igazolódott, 1 esetben a korábbi TRUSB eredményével megegyező gradusú tumort detektáltunk, és l esetben csak atípia (ASAP) mutatkozott a mintákban.

A PI-RADS 5. besorolású elváltozások esetében 91\%ban $(20 / 22)$, a PI-RADS 4 . besorolás esetén $85 \%$-ban (17/20), míg a PI-RADS 3. laesióknál 20\%-ban (2/10) igazolódott malignitás a szövettani feldolgozás során. A rosszindulatú daganat valószínűsége szignifikánsan magasabb volt PI-RADS 5 . besorolású elváltozások esetén, mint alacsonyabb PI-RADS-kategóriáknál, míg a PI-RADS 3. besorolás a jóindulatú elváltozás valószínúségét növelte $\left(\mathrm{khi}^{2}(2)=20,170, \mathrm{p}<0,001, \mathrm{~V}=0,623\right)$.

A tumorok elhelyezkedésének tekintetében elmondható, hogy perifériás zóna laesiói esetében szignifikánsan magasabb volt a pozitív biopsziás eredmény valószínúsége, mint a tranzicionális zóna elváltozásainál $\left(\mathrm{khi}^{2}(\mathrm{l})=\right.$ $6,555, \mathrm{p}=0,010$, Fisher-féle egzakt $\mathrm{p}=0,017, \mathrm{~V}=$ $0,355)$.

Az extraprosztatikus terjedés jeleinek megléte esetén nagyobb volt a pozitív minták valószínüsége $\left(\mathrm{khi}^{2}(\mathrm{l})=\right.$ $7,704, p=0,006$, Fisher-féle egzakt $\mathrm{p}=0,004, \mathrm{~V}=$ $0,355)$, mint olyan esetekben, melyekben nem merült fel az extraprosztatikus terjedés gyanúja az MR-vizsgálat alapján. Minden olyan esetben (17 eset) malignitás igazolódott, amelyben az MR-vizsgálat előzetesen extraprosztatikus terjedést jelzett.

Magasabb PSAD-értékek esetén a pozitív szövettani eredmény valószínüsége szignifikánsan magasabb volt $\left(0,47 \pm 0,50 \mathrm{ng} / \mathrm{ml}^{2}\right.$ vs. $0,18 \pm 0,17 \mathrm{ng} / \mathrm{ml}^{2} ; \mathrm{Z}=3,447$, p<0,001), míg önmagában a PSA-szint esetében nem igazolódott ilyen összefüggés $(22,6 \pm 28,3 \mathrm{ng} / \mathrm{ml}$ vs. $14,4 \pm 7,7 \mathrm{ng} / \mathrm{ml} ; \mathrm{Z}=-0,592, \mathrm{p}=0,554)$.

Összehasonlítottuk a prosztatavolument a negatív és a pozitív szövettani eredménnyel rendelkező betegek körében. Eredményeink alapján szignifikánsan magasabbnak bizonyult a prosztatavolumen abban a csoportban, amelyben az mpMR fúziós ultrahangvezérelt prosztatabiopszia során nem volt kimutatható malignitás $(50,9 \pm$ $18,8 \mathrm{ml}$ vs. $119,6 \pm 91,6 \mathrm{ml} ; \mathrm{Z}=-3,505, \mathrm{p}<0,001)$. 5 betegnél haladta meg a prosztatavolumen a $90 \mathrm{ml}-\mathrm{t}$, közülük egyik esetben sem igazolódott malignus tumor az mpMR fúziós biopszia során. A prosztata volumenével szemben az egyes laesiók volumene nem befolyásolta a mintavételek kimenetelét $(1,45 \pm 1,91 \mathrm{ml}$ vs. $1,31 \pm$ $1,18 \mathrm{ml} ; \mathrm{Z}=-0,592, \mathrm{p}=0,812)$.

\section{Megbeszélés}

Az elmúlt három évben, amióta az mpMR fúziós biopsziák elvégzését elkezdtük intézetünkben, az ajánlások megváltoztak. Amennyiben korábbi negatív TRUSB ellenére fennáll a klinikai gyanú daganat jelenlétére a PSA, RDV alapján, úgy mpMR-vizsgálat javasolt. Ezen esetekben PI-RADS $\geq 3$. esetén javasolt célzott biopszia, random biopszia nélkül. A biopszianaiv betegek esetében is lehet mpMR-vizsgálatot végezni klinikai gyanú esetén. Amennyiben ezeknél a betegeknél PI-RADS $\geq 3$. igazolódik, úgy random mintavétel is javasolt a célzott biopsziával együtt [13]. A jövőben ismételt biopszia esetén csak célzott mintavétel elvégzését tervezzük. Aktív követés esetén a megerősítő biopszia során célzott és random mintavétel is javasolt, a további mintavételek alkalmával viszont elegendő csak a gyanús elváltozásokból mintát venni [13]. A fenti ajánlásokat figyelembe véve sok felesleges biopszia elkerülhető, és a kezelőorvosok hamarabb diagnózishoz juthatnak. Ez csökkenti a felesleges biopsziák okozta szövődmények számát, és lehetővé teszi a korábban megkezdett kezelést.

Az elvégzett mpMR fúziós biopsziák során mútéti beavatkozást igénylő szövődmény nem lépett fel. A mintavételek transperinealisan történtek, ami irodalmi adatok alapján ritkábban jár szeptikus komplikációkkal a transrectalis biopsziákkal összehasonlítva, így ugyanis a prosztata nem kontaminálódik a rectalis baktériumflórával [14]. Ennek megfelelően a vizsgálatunkba bevont betegek körében csak 1 esetben lépett fel enyhe fertőzés. Teljes vizeletrekedés 4 betegnél alakult ki a mintavételeket követően. Húgycsősérülés elsősorban húgycsőhöz közeli, középvonali tumoroknál fordulhat elő, ilyen esetekben célszerú előre tájékoztatni a betegeket a magasabb szövődménykockázatról. Masszív haematuria 1 esetben fordult elő, mosókatéter alkalmazása elegendő volt a szövődmény elhárítására. Tapasztalataink alapján a transperinealis behatolás egyedüli hátránya, hogy a nagy méretü prosztatában lateralisan elhelyezkedő laesiók nehezen érhetők el a csípőcsontok miatt. A mintavételek spinalis anesztéziában történtek, de irodalmi adatok alapján a lidocainos helyi érzéstelenítés is megfelelő fájdalommentességet biztosít, ezért terveink szerint áttérünk erre a módszerre.

Összességében betegeink 80\%-ában került kimutatásra prosztatarák a minták szövettani feldolgozása során. Azokban az esetekben, amelyekben korábbi negatív TRUSB szerepelt a páciensek anamnézisében, 79\%-ban igazolódott malignitás a célzott mintavételt követően. Ez az arány magasabb, mint a szakirodalomban publikált legtöbb adat [15]. Az aktív követés részeként végzett célzott mintavételek 86\%-ában sikerült tumort kimutatnunk, a korábban ismertnél magasabb gradusú tumor 71\%-ban igazolódott. Ez az eredmény összhangban van azzal, hogy az MR-vizsgálat a klinikailag szignifikáns prosztatadaganat kimutatásában érzékeny. Magasabb gradusú tumor kimutatása esetén a betegek kezelése módosulhat, az addigi obszerváció helyett aktív kezelés válhat szükségessé.

A PI-RADS-besorolás tekintetében azt tapasztaltuk, hogy PI-RADS 5. laesiók esetében volt a legmagasabb a találati arányunk. A PI-RADS 4. elváltozásoknál szintén magas találati arányt észleltünk, míg a PI-RADS 3. laesiók csupán kis hányadánál igazolódott malignitás. A PI-RADS-besorolás segítségével a klinikailag szignifikáns 
prosztatatumor jelenlétének valószínüsége becsülhetó meg. Ez a valószínúség a PI-RADS 3. kategória esetében közepes, PI-RADS 4. besorolás esetén magas, míg PI-RADS 5. besorolás esetén nagyon magas [16]. Irodalmi adatok alapján a prosztatarák detekciós rátája mpMR fúziós biopsziával PI-RADS 3. laesiók esetén 5-26\% [17]. Az alacsony találati arány miatt az ilyen elváltozásoknál célzott mintavétel helyett MR-követés is indokolt lehet bizonyos esetekben, de a célzott mintavétel teljes mellőzése esetén a klinikailag szignifikáns prosztatatumorok bizonyos hányada diagnosztizálatlan maradna [18]. A saját és más munkacsoportok eredményeit figyelembe véve a továbbiakban is tervezzük célzott mintavételek végzését PI-RADS 3 . besorolás esetén, amenynyiben a klinikum ezt indokolja.

Eredményeink alapján a mintavételek kimenetelét az MR-vizsgálaton ábrázolódott elváltozások elhelyezkedése is befolyásolja. A perifériás zónából kiinduló laesiók esetében magasabb volt a felismerési ráta, mint a tranzicionális zóna elváltozásainak esetében. Ennek a jelenségnek részben az lehet a magyarázata, hogy a vizsgált betegpopulációban a tranzicionális zóna laesiói átlagosan alacsonyabb PI-RADS-besorolásúak voltak. Ezenkívül az is közrejátszhatott az eredmények alakulásában, hogy a tranzicionális zóna MR-diagnosztikája gyakran nem egyértelmû: egyes benignus eltérések tumort utánozhatnak, illetve előfordulnak atípusos megjelenésû tumorok is [19].

A laesiók lokalizációjával szemben azok mérete nem befolyásolta a mintavételek kimenetelét, vagyis az általunk használt fúziós eszköz kis méretű elváltozások esetében is pontos célzást tett lehetővé.

Az MR-vizsgálat alapján 17/40 esetben merült fel az extraprosztatikus terjedés gyanúja, a célzott mintavétel során minden ilyen esetben malignitás igazolódott. Az extraprosztatikus terjedés az agresszív viselkedésű, nagyobb kiterjedésű tumorokra jellemző, ez megmagyarázza hatékony kimutatásukat. Az ilyen tumorok kezelés nélkül magas mortalitással járnak, emiatt hatékony diagnózisuk kiemelt jelentőségű.

A betegek szérum-PSA-szintje és a mintavételek kimenetele között nem igazolódott összefüggés, viszont magasabb PSAD-értékek esetén nagyobb volt a pozitív minták valószínűsége. Ez az eredmény azzal az ismert megfigyeléssel magyarázható, hogy a PSAD a prosztatarák jelenlétének érzékenyebb markere, mint a szérumPSA-szint [20], emiatt a célzott mintavételre alkalmas páciensek kiválasztásában fontos szerepet játszik.

A prosztatatérfogat és a biopsziák kimenetele között inverz összefüggés igazolódott: magasabb prosztatavolumen esetén alacsonyabb volt a pozitív minták valószínüsége. Ennek a jelenségnek a hátterében több tényező szerepe is felmerül. A jóindulatú prosztatamegnagyobbodás PSA-szint-emelkedést okozhat, valaminta a prosztata tranzicionális zónájában megjelenhetnek olyan stromalis göbök, melyek tumort utánoznak. Ezenkívül jelentősen megnagyobbodott prosztatájú betegek eseté- ben az mpMR fúziós biopszia technikailag nehezebben kivitelezhető. A technikai nehézséget elsősorban az okozza, hogy az ultrahangvizsgálat során nem hozható látótérbe a teljes mirigyállomány. Ezek alapján a fúziós mintavétel indikációjának felállításakor tanácsos a prosztatavolumen figyelembevétele, ugyanis a jelentős fokú prosztatamegnagyobbodás limitáló tényező lehet.

\section{Következtetés}

Összefoglalásként elmondható, hogy az intézetünkben Magyarországon elsőként végzett mpMR fúziós biopsziák eredményessége magasabb az irodalmi átlagnál. Ennek elsősorban az lehet a magyarázata, hogy a limitált kapacitás miatt nagy hangsúlyt fektetünk az olyan páciensek kiválasztására, akik potenciálisan profitálhatnak a beavatkozásból. A célzott mintavételeket sikeresen alkalmaztuk olyan betegek körében, akiknél a korábbi szisztematikus mintavételek negatív eredményt adtak, valamint olyan esetekben is, amelyekben aktív követés jelentette a mintavételek indikációját. Eredményeink alapján a célzott mintavételre alkalmas páciensek kiválasztásakor célszerü figyelembe venni az MR-vizsgálaton ábrázolódott laesiók PI-RADS-besorolását, elhelyezkedését, a betegek PSAD-értékét és a prosztatavolument.

Anyagi támogatás: A közlemény megírása, illetve a kapcsolódó kutatómunka anyagi támogatásban nem részesült.

Szerzői munkamegosztás: A kézirat megírása: H. A. B., K. D. Á., L. M. Zs., Sz. A., Ny. P. A beavatkozások elvégzése: H. A. B., K. D. Á., Ny. P. Az MR-vizsgálatok kiértékelése: K. D. Á., L. M. Zs., R. G., K. I., F. B. Statisztikai elemzés: K. D. Á., T. Sz., Sz. J. A cikk végleges változatát valamennyi szerző elolvasta és jóváhagyta.

Érdekeltségek: A szerzőknek nincsenek érdekeltségeik.

\section{Irodalom}

[1] Ferlay J, Colombet M, Soerjomataram I, et al. Cancer incidence and mortality patterns in Europe: estimates for 40 countries and 25 major cancers in 2018. Eur J Cancer 2018; 103: 356-387.

[2] Rencz F, Brodszky V, Varga P, et al. The economic burden of prostate cancer. A systematic literature overview of registrybased studies. [A prosztatarák gazdasági terhe nagy betegregiszterek alapján. Irodalmi áttekintés.] Orv Hetil. 2014; 155: 509520. [Hungarian]

[3] Scosyrev E, Messing J, Noyes K, et al. Surveillance Epidemiology and End Results (SEER) program and population-based research in urologic oncology: an overview. Urol Oncol. 2012; 30: 126132.

[4] Shinohara K, Wheeler TM, Scardino PT. The appearance of prostate cancer on transrectal ultrasonography: correlation of imaging and pathological examinations. J Urol. 1989; 142: 7682.

[5] Jones JS. Saturation biopsy for detecting and characterizing prostate cancer. BJU Int. 2007; 99: 1340-1344. 
[6] Hoeks CM, Schouten MG, Bomers JG, et al. Three-Tesla magnetic resonance-guided prostate biopsy in men with increased prostate-specific antigen and repeated, negative, random, systematic, transrectal ultrasound biopsies: detection of clinically significant prostate cancers. Eur Urol. 2012; 62: 902-909.

[7] Trogdon JG, Falchook AD, Basak R, et al. Total medicare costs associated with diagnosis and treatment of prostate cancer in elderly men. JAMA Oncol. 2019; 5: 60-66.

[8] Bjurlin MA, Meng X, Le Nobin J, et al. Optimization of prostate biopsy: the role of magnetic resonance imaging targeted biopsy in detection, localization and risk assessment. J Urol. 2014; 192: 648-658.

[9] Cool DW, Zhang X, Romagnoli C, et al. Evaluation of MRITRUS fusion versus cognitive registration accuracy for MRI-targeted, TRUS-guided prostate biopsy. Am J Roentgenol. 2015 204: 83-91.

[10] Marks L, Young S, Natarajan S. MRI-ultrasound fusion for guidance of targeted prostate biopsy. Curr Opin Urol. 2013; 23: 43-50.

[11] Venderink W, Bomers JG, Overduin CG, et al. Multiparametric magnetic resonance imaging for the detection of clinically significant prostate cancer: what urologists need to know. Part 3: Targeted biopsy. Eur Urol. 2020; 77: 481-490.

[12] Siddiqui MM, Rais-Bahrami S, Turkbey B, et al. Comparison of $\mathrm{MR} /$ ultrasound fusion-guided biopsy with ultrasound-guided biopsy for the diagnosis of prostate cancer. JAMA 2015; 313: 390-397.

[13] Lam TB, MacLennan S, Willemse PM, et al. EAU-EANMESTRO-ESUR-SIOG prostate cancer guideline panel consensus statements for deferred treatment with curative intent for local- ised prostate cancer from an international collaborative study (DETECTIVE Study). Eur Urol. 2019; 76: 790-813.

[14] Grummet JP, Weerakoon M, Huang S, et al. Sepsis and 'superbugs': should we favour the transperineal over the transrectal approach for prostate biopsy? BJU Int. 2014; 114: 384-388.

[15] Wegelin O, Exterkate L, van der Leest M, et al. The FUTURE Trial: A multicenter randomised controlled trial on target biopsy techniques based on magnetic resonance imaging in the diagnosis of prostate cancer in patients with prior negative biopsies. Eur Urol. 2019; 75: 582-590.

[16] Weinreb JC, Barentsz JO, Choyke PL, et al. PI-RADS prostate imaging: reporting and data system -2015 , Version 2. Eur Urol. 2016; 69: 16-40.

[17] Scialpi M, Martorana E, Aisa MC, et al. Score 3 prostate lesions: a gray zone for PI-RADS v2. Turk J Urol. 2017; 43: 237-240.

[18] Schoots IG. MRI in early prostate cancer detection: how to manage indeterminate or equivocal PI-RADS 3 lesions? Transl Androl Urol. 2018; 7: 70-82.

[19] Yu J, Fulcher AS, Winks SG, et al. Diagnosis of typical and atypical transition zone prostate cancer and its mimics at multiparametric prostate MRI. Br J Radiol. 2017; 90: 20160693.

[20] Ohori M, Dunn JK, Scardino PT. Is prostate-specific antigen density more useful than prostate-specific antigen levels in the diagnosis of prostate cancer? Urology 1995; 46: 666-671.

(Hüttl András Béla dr., Budapest, Üllői út 78., 1082 e-mail: andrashuttl@gmail.com)

\section{"Semper plus metuit animus ignotum malum." (A bajtól, ha nem ismeri, mindig jobban fél a lélek.)}

A cikk a Creative Commons Attribution 4.0 International License (https://creativecommons.org/licenses/by/4.0/) feltételei szerint publikált Open Access közlemény, melynek szellemében a cikk bármilyen médiumban szabadon felhasználható, megosztható és újraközölhetö, feltéve, hogy az eredeti szerző és a közlés helye, illetve a CC License linkje és az esetlegesen végrehajtott módosítások feltüntetésre kerülnek. (SID_1) 